DOI: $10.19195 / 2084-5065.43 .7$

\title{
Esej o prawie do decydowania o niektórych przejawach życia osobistego
}

\author{
TEReSa DUKIET-NAGÓRSKA \\ Katedra Prawa Karnego i Kryminologii \\ Uniwersytet Śląski w Katowicach
}

W 2005 roku, a więc przed jedenastu laty, Jubilat zajął stanowisko w przedmiocie godnej śmierci, wyrażając $\mathrm{w}$ tej mierze ważkie opinie ${ }^{1}$. W okresie, który upłynął od tej wypowiedzi, nastąpiły pewne zmiany w myśleniu o tym fundamentalnym — zwłaszcza dla osób w bardziej niż średnim wieku, chorych czy skrajnie wyczerpanych dotychczasowym życiem — problemie. Nastąpiły też zmiany stanu prawnego, wydano judykaty o precedensowym charakterze. Mając to na względzie, podejmuję próbę kontynuacji myśli Profesora. Oczywiście przedstawione tu uwagi mogą się spotkać z Jego krytyką, lecz na wypadek takiej okoliczności powiem, że wagę argumentów Profesora wyznacza także to, jak dalece stanowią one inspirację dalszych wypowiedzi. Konstatacje miałkie nie mogą stanowić zaczynu dalszych — choćby nietrafnych — przemyśleń.

Prezentując swe stanowisko, Profesor powołuje się na relacje występujące między prawem, moralnością i zapatrywaniami tzw. opinii publicznej. Na tej drodze dochodzi do wniosku, że polski system prawa jest wprawdzie niespójny, lecz taki jego charakter stanowi etap pośredni. Owa niespójność wyraża się w tym, że pacjent może skutecznie odmówić poddania się interwencji medycznej ratującej $\dot{z ̇ y c i e}^{2}$, nie jest także kryminalizowana bezskuteczna próba samobójcza — a mimo to człowiek nie może uzyskać wsparcia otoczenia w zakresie realizacji stanowczej decyzji zakończenia życia przez tzw. dobrą śmierć, gdyż zarówno zabójstwo

1 T. Kaczmarek, Wolność dysponowania życiem a prawo do godnej śmierci. Rozważania o przestęstwie i karze, Warszawa 2006, s. $404 \mathrm{n}$.

2 Na straży tego uprawnienia stoją obecnie przepisy ustawy z dnia 6 listopada 2008 r. o prawach pacjenta i Rzeczniku Praw Pacjenta (Dz.U. z 2012 r. poz. 159, tekst jedn. z późn. zm.), ustawy z dnia 5 grudnia 1996 r. o zawodach lekarza i lekarza dentysty (Dz.U. z 2011 r. Nr 277, poz. 1634 z późn. zm.), ustawy z dnia 19 sierpnia 1994 r. ochronie zdrowia psychicznego (Dz.U. z 2016 r. poz. 546, tekst jedn. z późn. zm.), a także art. 192 k.k. 
eutanatyczne (art. $150 \S 1$ k.k.), jak i pomoc do samobójstwa (art. 151 k.k.) są w Polsce kryminalizowane. Profesor ocenę co do przejściowego charakteru takiego stanu prawnego wypowiada nie wprost, podkreśla jedynie, że istniejący stan rzeczy określić należy jako krok we właściwym kierunku, skoro w art. $150 \S 2$ k.k. przewidziano nie tylko możliwość nadzwyczajnego złagodzenia kary, lecz nawet odstąpienia od wymierzenia kary ${ }^{3}$. Jeśli dobrze odczytuję myśl Profesora, to w podtekście mówi tak: wszak na tym etapie już niewiele dzieli polskie społeczeństwo od rezygnacji z kryminalizacji dobrowolnej eutanazji czy wspomaganego samobójstwa.

Podzielam punkt widzenia Profesora co do ścisłej korelacji rozwiązań normatywnych z poziomem rozwoju społeczeństwa - tego wątku jednak nie poruszę. Podążając dalej tokiem Jego rozumowania, podejmuję próbę wskazania na dalsze właściwości obecnego systemu prawa, świadczące, moim zdaniem, o istnieniu obecnie przesłanek dopuszczenia eutanazji i wspomaganego samobójstwa. Kontynuując myśl Profesora, zajmę się także kwestią prawnokarnej irrelewantności niektórych innych decyzji dotyczących dóbr osobistych człowieka, a zwłaszcza prowadzących do ubezpłodnienia osób w wieku rozrodczym, choć w art. 156 $\S 1$ k.k. jako jeden z ciężkich uszczerbków na zdrowiu ustawa uznaje pozbawienie człowieka zdolności płodzenia. Na tych dwóch kwestiach koncentruje się moja wypowiedź, przy czym nie jest moim zamierzeniem całościowe ujęcie problemu — co tłumaczy użycie w tytule słowa „esej” — gdyż zważywszy na obfitość piśmiennictwa i poruszanych w nim wątków, jest to całkowicie nierealne w ramach jednego opracowania 4 .

Rozpocząć trzeba od podkreślenia, że polskie prawo medyczne opiera się na zasadzie autonomii pacjenta, której podstawową istotę określają przepisy pozostawiające człowiekowi prawo do odmowy poddawania się czynnościom leczniczym — nawet gdy odmowa taka oznacza śmierć lub uszczerbek na zdrowiu. W tej mierze podstawowe znaczenie mają art. 32 ust. 1 i art. 34 ust. 1 ustawy o zawodach lekarza i lekarza dentysty ${ }^{5}$ oraz — będący niemal lustrzanym ich odbiciem -

${ }^{3} \mathrm{~W}$ związku z treścią art. 150 § 2 k.k. jako niezamierzoną lukę w prawie ocenić trzeba brak przepisu przewidującego analogiczne uprawnienie odnośnie do wspomaganego samobójstwa. Wydaje się jednak, że w tym wypadku można zastosować analogię legis, albowiem jest to rozwiązanie korzystne dla sprawcy.

${ }^{4}$ Do zilustrowania tego bogactwa wystarcza rzut oka na publikacje o charakterze monografii: M. Szeroczyńska, Eutanazja i wspomagane samobójstwo na świecie. Studium prawno-porównawcze, Kraków 2004; P. Góralski, Prawne i spoteczne aspekty eutanazji, Kraków 2008; R. Citowicz, Prawnokarne aspekty ochrony życia człowieka a prawo do godnej śmierci, Warszawa 2006; J. Malczewski, Eutanazja. Gdy etyka zderza się z prawem, Warszawa 2012; Eutanazja, red. M. Mozgawa, Wrocław 2015 (praca zawiera materiały pokonferencyjne).

5 „Art. 32.1. Lekarz może przeprowadzić badanie lub udzielić innych świadczeń zdrowotnych, z zastrzeżeniem wyjątków przewidzianych w ustawie, po wyrażeniu zgody przez pacjenta”.

„Art. 34.1. Lekarz może wykonać zabieg operacyjny albo zastosować metodę leczenia lub diagnostyki stwarzającą podwyższone ryzyko dla pacjenta, po uzyskaniu jego pisemnej zgody”. 
art. 16 ustawy o prawach pacjenta i Rzeczniku Praw Pacjenta ${ }^{6}$. Naruszenie tych postanowień jest kryminalizowane (w ograniczonym zakresie) w art. 192 k.k.

Konieczne jest też nawiązanie do regulacji zawierających dozwolenie na dawstwo ex vivo jednego z parzystych narządów dla jego przeszczepienia ${ }^{7}$ — wszak następuje tu pomniejszenie funkcji organizmu w istotnym zakresie. Taki stan prawa znajduje usprawiedliwienie w idei przeszczepu jako działania ratującego życie lub zdrowie innej osoby, jednak nie sposób pominąć, że dawstwo nie tylko upośledza funkcje organizmu, jednak sam zabieg stwarza określone (właściwe każdej interwencji chirurgicznej) ryzyko dla życia. Prawo honoruje wolę człowieka, który kierując się względami ze wszech miar zasługującymi na uznanie, pomniejsza swe zdrowie i naraża życie na niebezpieczeństwo.

Honorowane jest także prawo kobiety do odmowy wyrażenia zgody na aborcję, zalecaną gdy ciąża i poród bezpośrednio zagrażają jej życiu. Taka decyzja stanowi formę zgody na śmierć, a mimo to polskie prawo nie przewiduje mechanizmu wymuszenia ochrony życia kobiety. Podobnie rzecz się ma w przypadku aborcji uzasadnionej zagrożeniem jej zdrowia.

Polskie prawo dopuszcza także poddawanie ludzi — za ich zgodą — eksperymentom badawczym, gdy występuje określone ryzyko uszczerbku na zdrowiu, uczestnik eksperymentu zaś nie odnosi zeń korzyści zdrowotnych (por. art. 21 ustawy o zawodach lekarza i lekarza dentysty).

Można zatem skonstatować, że polski system prawa w zakresie życia i zdrowia niekiedy zezwala człowiekowi na swobodne podejmowanie decyzji ich dotyczących - w tym nawet powodujących unicestwienie tych dóbr (oczywiście, jeśli ma on zdolność po temu, by takie decyzje podejmować). Kiedy indziej natomiast odmawia mu tego - gdy człowiek, kierując się swoim wyobrażeniem o tym, co jest dla niego dobre, w sposób przemyślany i stanowczy oczekuje wsparcia w zakończeniu swego życia czy upośledzeniu zdrowia w zakresie swej zdolności płodzenia. Celną ilustrację tego stanu prawa daje wypowiedź M. Płatek: „Przyjęte rozwiązania wskazują, że dla »dobra człowieka« można pominąć jego wolę"8.

Życie i zdrowie to dobra osobiste. Jest to w polskim systemie prawa niewątpliwe, choć nie ma ani legalnej definicji dóbr osobistych, ani enumeratywnego ich katalogu (w Konstytucji jest podrozdział, zatytułowany „Wolności i prawa osobiste", art. 23 k.c. zaś zawiera przykładowe wyliczenie dóbr osobistych). To

6 „Art. 16. Pacjent ma prawo do wyrażenia zgody na udzielenie określonych świadczeń zdrowotnych lub odmowy takiej zgody, po uzyskaniu informacji [...]".

7 W ustawie z dnia 1 lipca 2005 r. o pobieraniu, przechowywaniu i przeszczepianiu komórek, tkanek i narządów (Dz.U. z 2015 r. poz. 793, tekst jedn. z późn. zm.) zagadnieniu temu jest poświęcony rozdział 3 „Pobieranie komórek, tkanej i narządów od żywych dawców”).

8 M. Płatek, Eutanazja-Etikettenschwindel a prawo do dobrej śmierci, [w:] Eutanazja, s. 45. 
z kolei oznacza, że dobra te są objęte prawem do decydowania o swoim życiu osobistym, zagwarantowanym w art. $47 \mathrm{Konstytucji}^{9}$, a także w art. $8 \mathrm{EKPCz}^{10}$. Równocześnie te akty prawne przydają ochronę życiu (art. 38 Konstytucji ${ }^{11} \mathrm{i}$ art. 2 $\mathrm{EKPCz}^{12}$ ), zdrowiu (art. 68 ust. 1 Konstytucji). W tym stanie rzeczy zachodzi konieczność ustalenia relacji występującej pomiędzy ochroną życia i zdrowia z jednej strony a ochroną prawa do decydowania o swoim życiu osobistym.

Zarówno życie, jak i zdrowie nie są wartościami o charakterze absolutnym. Wniosek o względności ochrony życia wypływa zarówno z postanowień rangi ponadustawowej, jak i ustaw zwykłych.

Jest on oczywisty zwłaszcza w świetle treści art. 2 EKPCz. Dla roztrząsanych tu kwestii nie ma znaczenia stanowisko w przedmiocie sporu w kwestii dopuszczenia także horyzontalnego działania EKPCz, abstrahując zatem od tego problemu, można postawić tezę, że w pewnych okolicznościach — które ten przepis wskazuje - naruszenie życia człowieka wbrew jego woli nie jest bezprawne (do określenia tych okoliczności powrócę). Nie budzi także wątpliwości, iż z tych samych powodów dopuszczalne jest spowodowanie uszczerbku na zdrowiu (w tym przypadku argumentacja a maiore ad minus nie zawodzi).

Krótko mówiąc: niekiedy prawo zezwala na poświęcenie życia lub zdrowia wbrew woli dysponenta, niekiedy zaś pozwala na to w ramach prawa do samostanowienia, lecz nie dotyczy to dobrowolnej eutanazji, wspomaganego samobójstwa i dobrowolnej sterylizacji.

Także przepisy ustaw zwykłych, określające przypadki działania na rzecz ochrony życia i zdrowia człowieka z naruszeniem jego autonomii, świadczą

9 „Art. 47. Każdy ma prawo do ochrony prawnej życia prywatnego, rodzinnego, czci i dobrego imienia oraz do decydowania o swoim życiu osobistym”.

10 „Art. 8.1. Każdy ma prawo do poszanowania swojego życia prywatnego i rodzinnego, swojego mieszkania i swojej korespondencji. 2. Niedopuszczalna jest ingerencja władzy publicznej w korzystanie $\mathrm{z}$ tego prawa, z wyjątkiem przypadków przewidzianych przez ustawę i koniecznych w demokratycznym społeczeństwie z uwagi na bezpieczeństwo państwowe, bezpieczeństwo publiczne lub dobrobyt gospodarczy kraju, ochronę porządku i zapobieganie przestępstwom, ochronę zdrowia i moralności lub ochronę praw i wolności innych osób”. Między sposobem rozumienia prywatności w EKPCz a Konstytucją występuje różnica polegająca na tym, że konwencja w art. 8 ujmuje prywatność w sposób obejmujący także życie osobiste, podczas gdy w art. 47 Konstytucji wyodrębnia się ochronę życia prywatnego i ochronę prawa do decydowania o swoim życiu osobistym.

11 „Art. 38. Rzeczpospolita Polska zapewnia każdemu człowiekowi prawną ochronę życia”.

12 „Art. 2.1. Prawo każdego człowieka do życia jest chronione przez ustawę. Nikt nie może być umyślnie pozbawiony życia, wyjąwszy przypadki wykonania wyroku sądowego, skazującego za przestępstwo, za które ustawa przewiduje taką karę. 2. Pozbawienie życia nie będzie uznane za sprzeczne $\mathrm{z}$ tym artykułem, jeżeli nastąpi w wyniku bezwzględnie koniecznego użycia siły: a) w obronie jakiejkolwiek osoby przed bezprawną przemocą; b) w celu wykonania zgodnego z prawem zatrzymania lub uniemożliwienia ucieczki osoby pozbawionej wolności zgodnie z prawem; c) w działaniach podjętych zgodnie z prawem w celu stłumienia zamieszek lub powstania". 
o względnej ochronie tych dóbr, albowiem przymus leczenia w polskim prawie ujęty jest nader wąsko i zawsze podejmowany w imię ochrony określonych dóbr — przeważnie należących do innych osób. Przeciwstawne podejście do usytuowania życia i zdrowia wymagałoby ustanowienia bezwzględnego przymusu leczenia w każdym przypadku.

Prezentacja tych unormowań w sposób syntetyczny napotyka istotną barierę, wynikającą z ich szczegółowego charakteru, a także dlatego, że nader często odnoszą się one zarówno do czynności terapeutycznych, jak i nieterapeutycznych, podczas gdy podział na ochronę dóbr dzierżyciela dobra i ochronę dóbr należących do innych podmiotów ma znaczenie dla ocen dokonywanych z perspektywy prawa karnego. Niemniej jednak nie sposób ich pominąć w prowadzonych tu rozważaniach, gdyż odzwierciedlają kierunek działań ustawodawczych.

Doskonałą ilustrację prawidłowości występujących w polskim systemie prawa stanowią postanowienia ustawy z dnia 5 grudnia 2008 r. o zapobieganiu oraz zwalczaniu zakażeń i chorób zakaźnych u ludzi ${ }^{13}$. W ustawie tej, z uwagi na przedmiot regulacji, opisano liczne działania, których podjęcie może nastąpić przymusowo, a niekiedy nawet przy wykorzystaniu przymusu bezpośredniego ${ }^{14}$. W każdym przypadku jest to uzasadnione dążeniem do zabezpieczenia innych niż nosiciel lub osoba o to podejrzana - jednostek.

Przeprowadzanie obowiązkowych czynności diagnostycznych i terapeutycznych przewidują także przepisy k.k.w., pośród których najbardziej skrajną postać stanowi art. 118, dopuszczający przymusowe poddanie skazanego odbywającego karę pozbawienia wolności nawet zabiegowi chirurgicznemu. Rozwiązanie to oznacza, że człowiek mający zdolność decydowania o swoim życiu i zdrowiu traci ją po przekroczeniu murów zakładu karnego. Jest to o tyle usprawiedliwione, że celów postępowania wykonawczego nie sposób realizować, gdy skazany jest w stanie zdrowia wymagającym zabiegu chirurgicznego. Oczywiście także w warunkach izolacji więziennej występują przypadki podejmowania działań z uwagi na niebezpieczeństwo, jakie skazany stwarza dla otoczenia.

Uwzględnienia wymagają także postanowienia ustawy o ochronie zdrowia psychicznego, która zawiera obszerne regulacje tyczące się postępowania opartego na przymusie. Działania o takim charakterze są w niej przewidziane głównie dla ochrony dóbr prawnych nienależących do pacjenta, a jego życie i zdrowie chronione jest z zastosowaniem przymusu, tylko gdy istnieją podstawy dla przyjęcia, że brak zgody na interwencje medyczne wynika z zaburzeń psychicznych, a więc odmowa nie pochodzi od osoby zdolnej do świadomego jej wyrażenia. W pozo-

13 Dz.U. z 2013 r. poz. 947, tekst jedn. z późn. zm.

14 Przepisem ogólnym, zawierającym wyliczenie obowiązków spoczywających na osobach przebywających na terytorium RP jest art. 5, w którym wymienia się m.in. poddawanie się zabiegom sanitarnym, szczepieniom ochronnym, kwarantannie, izolacji, leczeniu, hospitalizacji. Ustawa określa, w licznych dalszych przepisach, szczegółowe warunki tego dotyczące. 
stałym zakresie pacjent wykazujący zaburzenia psychiczne traktowany jest tak jak pozostali pacjenci — interwencje medyczne wymagają jego zgody ${ }^{15}$. Krótko mówiąc, ustawa o ochronie zdrowia psychicznego zezwala na działanie z naruszeniem autonomii pacjenta $\mathrm{w}$ dwóch grupach przypadków: gdy zagrożone jest dobro prawne należące do innego niż pacjent podmiotu oraz gdy stan psychiczny pacjenta uzasadnia przypuszczenie, że nie pojmuje on właściwie swego interesu.

Zbliżony charakter mają przepisy, anachronicznej już, ustawy z dnia 26 października 1982 r. o wychowaniu w trzeźwości i przeciwdziałaniu alkoholizmo$\mathrm{wi}^{16}$ oraz postanowienia ustawy z dnia 29 lipca 2005 r. o przeciwdziałaniu narkomanii ${ }^{17}$, w których jako zasadę przyjmuje się dobrowolność terapii odwykowej — przy jednoczesnym ustanowieniu wyjątków w tej mierze, uzasadnionych albo ochroną dóbr należących do innych niż osoba uzależniona podmiotów, albo małoletniością.

Obowiązek poddania się leczeniu wiąże się z istotą leczniczych środków zabezpieczających, przewidzianych w kodeksie karnym, obowiązek taki jest nakładany także jako element probacji (art. art. 67 § $3,72 \S 1$ pkt 6 i $6 a^{18}$ ). W tych przypadkach jest to podyktowane funkcją zabezpieczającą prawa karnego.

Odrębnego potraktowania wymagają przepisy kodeksu postępowania karnego (art. $74 \S 2$ pkt 2), przewidujące przymusowe badania, gdyż nie mają one charakteru leczniczego. Działania te wiążą się z pewnym ryzykiem dla osoby im poddawanej, a mimo to są przeprowadzane, bo bez nich cele postępowania karnego nie zostaną osiągnięte. Zatem bezpieczeństwo w zakresie zdrowia niewątpliwie nie ma tu prymatu.

Podsumowując ten etap rozważań, można powiedzieć tak: zgodne z prawem jest naruszenie w pewnych okolicznościach życia i zdrowia człowieka wbrew jego woli, zawsze jednak odbywa się to w imię ochrony określonych wartości, a to oznacza, że nie jest wartością absolutną. W pewnych zaś okolicznościach jednostka ma prawo poświęcić swe życie lub zdrowie, nie dotyczy to jednak dobrej śmierci i sterylizacji. A skoro tak, to konieczna jest diagnoza dotycząca powodów, dla których prawo zmusza człowieka „do kurczowego przedłużania starości lub stanów zaawansowanego fizycznego lub umysłowego zniedołężnienia"19, a także ingeruje $\mathrm{w}$ sferę jego seksualności przez zakaz powodowania utraty zdolności płodzenia.

$15 \mathrm{~W}$ art. 18 uregulowano stosowanie przymusu bezpośredniego, w art. 21 zaś badanie psychiatryczne bez zgody, natomiast kolejne przepisy dotyczą hospitalizacji.

16 Dz.U. z 2016 r. poz. 487, tekst jedn. z późn. zm.

17 Dz.U. z 2016 r. poz. 224, tekst jedn. z późn. zm.

18 To samo jest charakterystyczne dla warunkowego zwolnienia, albowiem w art. $159 \S 1$ k.k.w. odsyła do art. $72 \S 1$ k.k.

19 Cytat pochodzi z wyroku ETPCz z dnia 14 maja 2013 r., Gross v. Szwajcaria - 67810/10, LEX 1314328. 
Rysuje się pytanie: dlaczego prawo nie dopuszcza naruszenia życia i zdrowia stosownie do świadomej i dobrowolnej decyzji osoby, do której to dobro należy? Jaka inna wartość ma stanowić uzasadnienie takiego stanu rzeczy, skoro prawo do decydowania o swoim życiu osobistym jest chronione na poziomie ponadustawowym - tu ponownie wskazać należy na art. 8 EKPCz i art. 47 Konstytucji?

W dotychczasowych opracowaniach powodów ograniczenia prawa do decydowania o swoim życiu i zdrowiu dopatrywano się w kategoryzacji dóbr prawnych. Rozważania o tej mierze spotkać można zwłaszcza w publikacjach poświęconych zgodzie uprawnionego.

Przytoczę tu - jako charakterystyczne dla dominującego kierunku w doktrynie - trzy wypowiedzi oparte na szerokiej prezentacji stanowiska doktryny, co zwalnia mnie od drobiazgowej relacji w tym względzie.

P. Daniluk przytacza podział dóbr prawnych, dokonany przez M. Cieślaka, który odróżnił trzy ich kategorie:

— dobra ściśle indywidualne, którymi jednostka może swobodnie dysponować;

— dobra ściśle społeczne;

- dobra zarazem indywidualne i społeczne.

Następnie zaś autor ten wskazuje, że swoboda dysponowania dobrem dotyczy tylko pierwszej z tych kategorii, ponadto podkreśla, że spełnione być musi kryterium zgodności z zasadami współżycia społecznego i dobrymi obyczajami ${ }^{20}$.

\section{J. Długosz pisze:}

Katalog dóbr prawnych, którymi jednostka może swobodnie dysponować, nie jest [...] wyraźnie określony przez prawo, lecz wynika z jego wykładni. Istnieją bowiem dobra prawne, którymi dysponent może rozporządzać swobodnie (np. wolność, mienie). Natomiast niektóre dobra prawne, chroniące interes jednostki, nie mogą być swobodnie naruszane, nawet za zgodą ich dysponenta i bez względu na ich wolę. Wynika to zwłaszcza z przekonania, że w określonych okolicznościach naruszenie dobra prawnego o charakterze indywidualnym godzi nie tylko w interes jednostki, ale może stanowić także naruszenie interesu społecznego ${ }^{21}$.

Autorka ta omawia równocześnie, wskazywane w doktrynie, racje stanowiące przeciwwskazanie zezwolenia na wyrażanie zgody na naruszenie życia ludzkiego. Przywołuje nieodwracalność zarówno zgody, jak i czynu popełnionego w jej rezultacie, czemu towarzyszą trudności dowodowe. Słusznie jednak uznaje, że trudności dowodowe nie mogą stanowić podstawy rozstrzygnięć materialnoprawnych. Przywołuje także argument, w myśl którego akceptacja prawa do samostanowienia w tym zakresie nie jest możliwa, albowiem funkcjonowanie społeczeństwa

20 P. Daniluk, Kryteria określające zakres dóbr prawnych będących przedmiotem dyspozycji $w$ warunkach kontratypu zgody uprawnionego, PS 2007, nr 4, s. 94.

21 J. Długosz, Zgoda dysponenta dobrem prawnym w'świetle regulacji konstytucyjnych. Rozważania na pograniczu konstytucyjnego prawa jednostki do samostanowienia o sobie i dogmatyki prawa karnego, [w:] Zgoda pokrzywdzonego, red. R. Zawłocki, Warszawa 2012, s. 3. 
nie jest możliwe bez fizycznego istnienia jego członków. Przeciwstawiając się tej tezie, wskazuje na niekonsekwencję ustawodawcy, polegającą na braku karalności za nieudane samobójstwo. Odrzuca także paternalistyczny pogląd o potrzebie chronienia człowieka przed samym sobą.

Wedle tej autorki „żądanie jednostki wyrażające jej wolę eutanazji, nie stanowi okoliczności mogącej usprawiedliwić pozbawienie jej życia ze względu na sprzeczność ze społecznie uzasadnionymi normami moralnymi”"22. Jest także zdania, że tezę tę odnieść można do innych typizacji znamiennych zgodą uprawnionego.

Interesujące wywody na temat paternalizmu prawa i ludzkiej wolności prezentuje J. Piskorski, dla którego ograniczenia wolności mogą być realizowane ze względu na cele utylitarne prawa karnego, a także ze względów moralnych ${ }^{23}$. Autor ten przytacza poglądy zarówno absolutyzujące autonomię człowieka, jak i określane przezeń jako „łagodny paternalizm” (uzasadniany brakiem racjonalności czy brakiem zdolności osoby do wyrażania zgody na dany czyn) i konkluduje: „błędem jest postrzeganie zasady volenti jako zasady o charakterze prymarnym w prawie karnym") ${ }^{24}$.

J. Długosz i J. Piskorski oczywiście mają rację, odwołując się do względów natury moralnej. Jednakże argument na tym poziomie ogólności nie może być zaaprobowany ze względu na brak zakotwiczenia argumentacji w pogłębionych rozważaniach o relacji pomiędzy prawem i moralnością, a także brak uwzględnienia mnogości systemów moralnych ${ }^{25}$. Ponadto w tych wypowiedziach niewystarczająco wykorzystano aksjologię polskiego systemu prawa, odzwierciedloną w przepisach Konstytucji i aktach prawa międzynarodowego, stanowiących część składową wewnętrznego porządku prawnego. W moim przekonaniu w rozważaniach posadowionych w systemie prawa kontynentalnego, do którego zaliczyć trzeba, prawo polskie, nie mogą być pominięte treści normatywne.

Prawo - mniej lub bardziej precyzyjnie — wskazuje dobra prawne, w imię ochrony których może następować naruszenie autonomii człowieka. Szczególne znaczenie w tej materii ma zasada proporcjonalności, wyrażona w art. 31 ust. 3 Konstytucji ${ }^{26}$. W ten sposób ustrojodawca wskazuje, w imię jakich dóbr dokonywać można w ustawie zwykłej ograniczenia praw i wolności człowieka, co odnosi

22 Ibidem, s. 9-101.

23 J. Piskorski, Volenti non fit iniuria - niedoceniana czy przeceniana zasada prawa karnego?, [w:] Zgoda..., s. 14-15.

24 Ibidem, s. 28.

25 O ogromnym zróżnicowaniu w tej mierze świadczą liczne prace — np. praca zbiorowa $\mathrm{Me}$ dycyna a prawa człowieka, Warszawa 1996; praca zbiorowa Lekarz a prawa człowieka, Toruń 1996.

26 „Art. 31. [...] 3. Ograniczenia w zakresie korzystania z konstytucyjnych wolności i praw mogą być ustanawiane tylko w ustawie i tylko wtedy, gdy są konieczne w demokratycznym państwie dla jego bezpieczeństwa lub porządku publicznego, bądź dla ochrony środowiska, zdrowia i moralności publicznej, albo wolności i praw innych osób [...]”" 
się m.in. do prawa człowieka do decydowania o swoim życiu osobistym. Dobra prawne, których ochrona może stanowić uzasadnienie uszczuplenia autonomii człowieka, są ujęte nader ogólnie i tworzą bardzo szeroką paletę, niemniej jednak nie można pośród nich dopatrzyć się mechanizmu ograniczania jednego dobra osobistego należącego do danego podmiotu kosztem drugiego dobra osobistego należącego do tego samego podmiotu, o ile jest to podmiot mający zdolność stanowienia o sobie. W tym przepisie wymienione są jedynie dobra prawne o charakterze ogólnospołecznym oraz prawa i wolności innych osób.

W rozważaniach dotyczących zakresu ochrony życia musi być uwzględniony art. 2 EKPCz, gdyż jest on wskazywany przez skarżących jako podstawa uznania niezgodności przepisów krajowych — zakazujących czy też niezezwalających na dobrą śmierć — z EKPCz.

W tej mierze szczególne znaczenie ma skarga Diane Pretty ${ }^{27}$. Skarżąca cierpiała na nieuleczalną chorobę powodującą zwyrodnienie i zanik mięśni, której postęp spowodował zupełne jej uzależnienie od otoczenia (była całkowicie sparaliżowana), nadto w dalszej perspektywie czekała ją, najprawdopodobniej, śmierć przez uduszenie w wyniku atrofii mięśni odpowiedzialnych za oddychanie. Zachowała jednakże sprawność psychiczną pozwalającą na komunikowanie się z otoczeniem. Wystąpiła do Dyrektora Urzędu Oskarżycielskiego (za pośrednictwem pełnomocników), by zagwarantował jej mężowi bezkarność, jeśli ten — na podstwie jej żądania - ułatwi jej zakończenie życia. Odmowa spowodowała rozpoznanie sprawy przez sądy krajowe, które uznały, że pomoc do samobójstwa jest sprzeczna nie tylko z prawem krajowym, lecz także z EKPCz. Wobec tego sądy krajowe odmówiły uwzględnienia jej żądania. W tej sytuacji Diane Pretty wystąpiła ze skargą do ETPCz. Przedstawiła nader interesującą argumentację, w ramach której podjęła próbę wykazania, że stanowisko to oznacza naruszenie m.in. art. 2, $3^{28}$ i $8^{29}$ EKPCz. Trybunał odrzucił jej skargę, argumentując, iż „,bez wypaczenia treści art. 2 Konwencji nie można tego przepisu interpretować jako źródła całkowicie przeciwnego prawa, mianowicie prawa do śmierci; nie kreuje on też prawa do samorealizacji rozumianej jako prawo jednostki do wyboru raczej śmierci niż

27 Wyrok ETPCz z dnia 29 kwietnia 2002 r., w sprawie Pretty v. Zjednoczone Królestwo, skarga nr 2346/02, LEX 75647; oraz Prawo wobec medycyny $i$ biotechnologii, red. M. Safjan, Wrocław 2011, s. 97-101.

28 Art. 3 EKPCz: „Nikt nie może być poddany torturom ani nieludzkiemu lub poniżającemu traktowaniu albo karaniu".

29 Art. 8 EKPCz: „1. Każdy ma prawo do poszanowania swojego życia prywatnego i rodzinnego, swojego mieszkania i korespondencji. 2. Niedopuszczalna jest ingerencja władzy publicznej w korzystanie $\mathrm{z}$ tego prawa, $\mathrm{z}$ wyjątkiem przypadków przewidzianych przez ustawę i koniecznych $\mathrm{w}$ demokratycznym społeczeństwie z uwagi na bezpieczeństwo państwowe, bezpieczeństwo publiczne lub dobrobyt gospodarczy kraju, ochronę porządku i zapobieganie przestępstwom, ochronę zdrowia i moralności lub ochronę praw i wolności innych osób”. 
życia"30. Trybunał stwierdził, iż art. 2 EKPCz nie daje jednostce żadnego prawa wymagania od państwa zezwolenia lub ułatwienia śmierci. Diane Pretty argumentowała także, że brak dozwolenia na jej godną śmierć oznacza zmuszanie jej do życia w okolicznościach stanowiących nieludzkie, poniżające traktowanie. W odpowiedzi Trybunał ocenił, że o nieludzkim, poniżającym traktowaniu nie może być mowy, wówczas gdy cierpienie stanowi rezultat procesu chorobowego rozwijającego się niezależnie od czynników zewnętrznych (takich jak np. złe traktowanie czy brak dostatecznej opieki ze strony służb medycznych). Diane Pretty broniła nadto tezy, że zmuszanie jej do życia w okolicznościach, które uznaje za naruszające jej godność stanowi naruszenie prawa do decydowania o swoim życiu prywatnym w rozumieniu art. 8 EKPCz. Trybunał uznał, że niemożność dokonania przez skarżącą wyboru pomiędzy kontynuacją niegodnego (w jej ocenie) życia a śmiercią może oznaczać naruszenie prywatności i stwierdził:

Istotą konwencji jest poszanowanie dla ludzkiej godności i wolności. Nie negując w żaden sposób zasady świętości życia chronionej przez konwencję, Trybunał uznaje, że na podstawie art. 8 coraz większego znaczenia nabiera jakość życia. W erze ogromnego postępu w medycynie i wzrostu średniej długości życia dla wielu osób staje się ważne, aby nie zmuszano ich do dożywania podeszłego wieku lub do życia w stanie zaawansowanej niedołężności fizycznej bądź umysłowej, w konflikcie z wyznawanymi przez nich poglądami o własnej osobie i tożsamości.

Jednakże jego zdaniem prawo krajowe nieprzewidujące prawa do godnej śmierci (kryminalizujące pomoc do samobójstwa) służy ochronie innych istnień ludzkich, które mogłyby doznać uszczerbku w wyniku nadużywania eutanazji. Dopuszczenie eutanazji jako prawa jednostki mogłoby się negatywnie odbić na jednostkach słabych i bezbronnych. Wedle Trybunału ingerencja w prywatność jest usprawiedliwiona obawą nadużyć tego rodzaju. Opisane stanowisko Trybunału w przedmiocie ,prawa do godnej śmierci” zostało podtrzymane w późniejszych orzeczeniach poświęconych naruszeniu konwencyjnej ochronie prywatności z uwagi na brak możliwości skorzystania przez skarżących z dostępu do substancji powodującej bezbolesną śmierć ${ }^{31}$. Mając na uwadze jądro omawianego tu problemu, warto bliżej przedstawić wyrok ETPCz w sprawie M.A. Gross v. Szwajcaria z dnia 14 maja 2013 r., a to dlatego że w tym kraju podżeganie i pomoc do samobójstwa są karalne jedynie w przypadku „samolubnej motywacji”, w czego konsekwencji w orzecznictwie szwajcarskiego Federalnego Sądu Najwyższego

30 Cytat pochodzi z tłumaczenia własnego M. Wąsek-Wiaderek, „Prawo do godnej śmierci” w orzecznictwie Europejskiego Trybunału Praw Człowieka, [w:] Eutanazja, s. 287.

31 Por. np. wyrok ETPCz z dnia 20 stycznia 2011 r. w sprawie M.A. Haas przeciwko Szwajcarii, skarga nr 31322/07, LEX 694186; wyrok ETPCz z dnia 19 lipca 2012 r., w sprawie Koch v. Niemcy, skarga nr 497/09, LEX 1191974; wyrok ETPCz z dnia 14 maja 2013 r. w sprawie Gross v. Szwajcaria, skarga nr 67810/10, LEX 1314328. 
ukształtowała się linia orzecznicza, zgodnie z którą lekarz może przepisać pentobarbital sodu, aby umożliwić pacjentowi samobójstwo — o ile jest to zgodne $z$ warunkami wypracowanymi przez ten sąd. W istocie oznacza to odesłanie do wytycznych etyki lekarskiej, dotyczących sprawowania opieki nad osobami u schyłku życia, wydanymi przez organizację pozarządową (wytyczne te nie mają cech aktu prawnego). W myśl tych wytycznych takie postępowanie lekarza dotyczy jedynie pacjentów, u których rozpoczął się proces, wedle przewidywania lekarza prowadzący do śmierci w ciągu kilku dni lub tygodni. Skarżąca nie znajdowała się w takim stanie.

W postępowaniu przed Trybunałem nie przedstawiono

żadnych innych materiałów zawierających zasady lub standardy, które mogłyby posłużyć za wytyczne co do tego, czy i w jakich okolicznościach lekarz jest uprawniony do wydania recepty na pentobarbital sodu pacjentowi, takiemu jak skarżąca, która nie cierpi na śmiertelną chorobę. [...] Ten brak wyraźnych wytycznych może wywierać zniechęcający wpływ na lekarzy, którzy w innym przypadku mogliby wydać osobie takiej jak skarżąca receptę na wskazany lek.

Taki stan rzeczy stanowił podstawę uznania, że doszło do naruszenia art. 8 EKPCz, gdyż:

— ,prawo szwajcarskie, dopuszczając możliwość podania śmiertelnej dawki pentobarbitalu sodu na zlecenie lekarskie, nie zapewniło wystarczających gwarancji dających jasność co do zakresu stosowania tego prawa"

— ,to przede wszystkim do władz krajowych należy wydanie szerokich i wyraźnych wytycznych co do tego, czy i na jakich warunkach osoba w sytuacji skarżącej — czyli ktoś, kto nie cierpi na chorobę śmiertelną — powinien mieć możliwość uzyskania śmiertelnej dawki leku pozwalającej na zakończenie życia”.

Podsumowując, można powiedzieć, że w kwestii dopuszczenia dobrowolnej i świadomej eutanazji Trybunał uznaje kompetencję władz krajowych do wyważenia zakresu ochrony życia i zakresu ochrony prawa do prywatności, którego część składową stanowi prawo do zakończenia życia zgodnie z własną wolą. Jego zdaniem z postanowień konwencji nie sposób wywieść obowiązku państw do zapewnienia jej obywatelom godnej śmierci, niemniej jednak obecnie dostrzega on problem tych osób, które przedkładają jakość życia ponad jego długość. W razie dopuszczenia tej formy eutanazji konieczne jest jasne i precyzyjne wytyczenie przesłanek warunkujących jej legalność.

Celowe jest tu przywołanie wypowiedzi Trybunału pochodzącej z wyroku w sprawie Diane Pretty. W tym judykacie Trybunał zawarł ważką konstatację, a mianowicie powołał się na to, że ,przyjmuje dynamiczne i elastyczne podejście do interpretacji Konwencji, która jest żyjącym instrumentem prawnym”, niemniej 
jednak „każda interpretacja Konwencji musi być zgodna z jej podstawowymi celami oraz systemem ochrony prawa człowieka".

W moim przekonaniu wypowiedź Trybunału wskazująca na występującą $\mathrm{u}$ wielu ludzi potrzebę dobrej śmierci, w powiązaniu z elastycznym podejściem do interpretacji EKPCz, uprawnia do tezy o stopniowym liberalizowaniu przez Trybunał podejścia do problemu eutanazji. Nie sposób jednak nie zwrócić uwagi na to, że równocześnie Trybunał odczytuje art. 8 ust. 2 EKPCz w sposób, który temu oczekiwaniu przeczy, albowiem główna myśl Trybunału brzmi tak: poszczególne kraje mogą dopuścić dobrowolną i świadomą eutanazję bez naruszenia art. 2 Konwencji, o ile określą jej przesłanki w sposób, który pozwoli ochronić jednostki słabsze (fizycznie lub psychicznie) przed poddawaniem ich procederowi przymusowego skracania życia. Oznacza to, że zdaniem Trybunału naruszenie prawa do samostanowienia osoby, która chce świadomie i dobrowolnie skrócić swoje życie - wynikające z kryminalizacji eutanazji i pomocy do samobójstwa — jest usprawiedliwione niebezpieczeństwem nadużywania tego prawa. Myślenie w tych kategoriach wynika z doświadczeń przeszłości, kiedy do dochodziło do eksterminacji chorych psychicznie i przymusowo sterylizowano określone grupy ludności. Można wszakże przeciwstawić temu doświadczenie demokratycznych krajów, w których przeprowadzana jest obecnie procedura eutanazji dobrowolnej (wspomaganego samobójstwa) i dobrowolnej sterylizacji w sposób pozwalający na zniwelowanie takiego zagrożenia. Ponadto rozumowanie Trybunału odbiega od literalnego brzmienia art. 8 ust. $2 \mathrm{EKPCz}$, w którym stanowi się, że ingerencja władzy publicznej w sferę życia prywatnego jest dopuszczalna m.in. ze względu „ochronę zdrowia i moralności lub ochronę praw i wolności innych osób”, a zatem idzie tu o przypadek, gdy korzystanie z prawa do samostanowienia prowadzi samo w sobie do powstania niebezpieczeństwa dla innych osób (np. gdy ograniczenie to jest spowodowane chorobą zakaźną), a nie o potencjalne zagrożenie wynikające z możliwych w przyszłości zachowań innych osób.

Wywody Trybunału są także wewnętrznie sprzeczne, albowiem skoro Trybunał dopuszcza decyzję poszczególnych krajów o legalizacji eutanazji (wspomaganego samobójstwa), to znaczy, iż uznaje istnienie realnej możliwości takich unormowań, które nie będą naruszały art. 8 ust. 2 EKPCz. Skoro Trybunał zgadza się z tym, że prawo do prywatności obejmuje prawo do wyboru momentu i formy zakończenia życia, to implikuje to obowiązek państwa zapewnienia realizacji tego prawa, gdyż jest to możliwe. A jeśli tak, to usprawiedliwiony staje się zarzut braku uzasadnienia odrzucenia skargi Diane Pretty (a w konsekwencji tego — także pozostałych skarg). Powyższe uwagi, mutatis mutandis, odnoszą się do dobrowolnej sterylizacji.

Konkludując, można stwierdzić, że ani w treści art. 31 ust. 3 Konstytucji, ani też art. 8 ust. 2 EKPCz nie sposób dopatrzyć się postanowień sprzeciwiających się uznaniu dobrej śmierci i dobrowolnej sterylizacji za legalne. Zważywszy jed- 
nak na wagę problemu i brak jednomyślności co do kierunku jego rozstrzygania, płaszczyzna zgody uprawnionego, choć jest wystarczająca do uzyskania pozytywnego rezultatu (przy czym nie ma tu znaczenia, czy wybierze się konstrukcję pierwotnej, czy wtórnej legalności), nie pozwoli na uwolnienie od dalszych sporów. Mając to na względzie, optuję za rozwiązaniem ustawowym. Póki nie będzie po temu w Polsce klimatu, rozwiązania pozaustawowe, wedle mego głębokiego przekonania, mogą, i powinny, stanowić podstawę do orzeczniczych decyzji. Innymi słowy: w okresie przejściowym zgoda uprawnionego powinna być wykorzystana do legalizacji dobrej śmierci. Jak sądzę, powyższe uwagi upoważniają do stwierdzenia, że Jubilat nader trafnie przewidywał kierunek ewoluowania stanu prawnego i myślenia o dobrej śmierci.

\section{Essay on the right to decide about some aspects of personal life}

\section{Summary}

The essay is a reference to the statement of Professor T. Kaczmarek about the human right to a good death in Polish law. The starting point is recalling the provisions constituting the normative autonomy for refusing life-saving medical interventions, refusing abortion needed to save the lives or health of pregnant women and consent to organ donation ex vivo. These normative regulations are confronted with the criminalisation of the murder at the request of the victim (and under the influence of sympathy for her) and assisted suicide, as well as provisions permitting the forced treatment. The common ground is the principle of proportionality, as well as the provisions of the Constitution defining the protection of life and health, and the right to self-determination about personal life.

Keywords: a "good death", euthanasia murder, assisted suicide, sterilization, patient autonomy, principle of proportionality. 